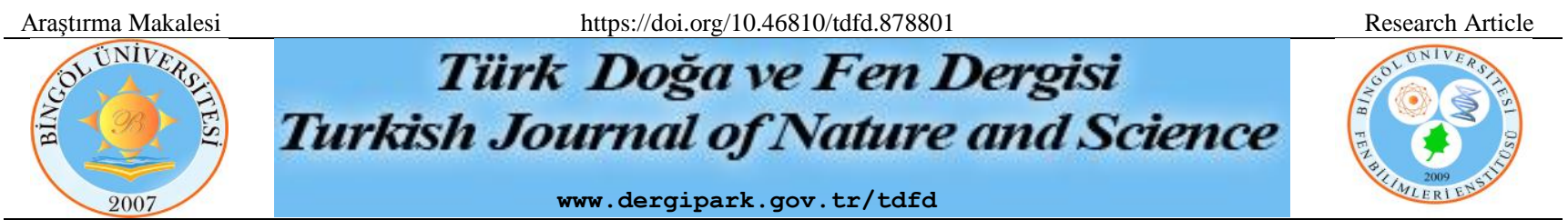

\title{
Karasal İklim Şartlarında Bazı Fasulye (Phaseolus vulgaris L.) Genotiplerinin Kuru Otlarının Hayvan Yemi Olarak Kullanım Potansiyelinin Belirlenmesi
}

\author{
İbrahim KILINÇ ${ }^{1}$, Ömer Süha USLU ${ }^{2 *}$ \\ ${ }^{1}$ Kahramanmaraş Sütçü İmam Üniversitesi, Ziraat Fakültesi, Tarla Bitkileri Bölümü, Kahramanmaraş, Türkiye \\ ${ }^{2}$ Kahramanmaraş Sütçü İmam Üniversitesi, Ziraat Fakültesi, Tarla Bitkileri Bölümü, Kahramanmaraş, Türkiye \\ İbrahim KILINÇ ORCID No: 0000-0002-4292-1639 \\ Ömer Süha USLU ORCID No: 0000-0003-0858-0305
}

*Sorumlu yazar: suhauslu@ksu.edu.trr

(Alınış: 11.02.2021, Kabul: 21.05.2021, Online Yayınlanma: 25.06.2021)

\begin{abstract}
Anahtar
Kelimeler

Fasulye,

Ot kalitesi,

Ot verimi,

NDF ve ADF

oran1,

Ham protein

oran1

Öz: $\mathrm{Bu}$ araştırma, önemli bir fasulye üretim havzası olan ve tipik karasal iklim özellikleri sergileyen Kahramanmaraş İli Afşin İlçesinde yetiştirilebilecek yüksek verimli fasulye genotiplerinde dane hasadı artıklarının kaba yem olarak kalite değerlerini belirlemek amacıyla 2018 yılında yürütülmüştür. Araştırmada 40 sırık, 30 oturak olmak üzere toplam 70 farklı fasulye (Phaseolus vulgaris L.) genotipi test edilmiştir. Deneme tesadüf blokları deneme desenine göre düzenlenmiş̧ir. Araştırmada kuru ot verimi, ham protein oranı ve verimi, ham kül, nötr deterjanda çözünmeyen lif (NDF) ve asit deterjanda çözünmeyen lif (ADF) oranı ve nispi yem değerleri saptanmıştır. Araştırma sonuçlarına göre; fasulye genotipleri arasında incelenen tüm özellikler açısından istatistiki olarak önemli farklılıklar bulunmuştur. Kuru ot verimi $129,7-978,0 \mathrm{~kg} \mathrm{da}^{-1}$, ham protein oran $\% 5,65-15,52$, ham protein verimi $8,31-143,63 \mathrm{~kg} \mathrm{da}^{-1}$, ham kül oranı $\% 5,29-28,81$, NDF oran $\% 48,15-80,00$, ADF oran1 $\% 28,00-58,00$ ve nispi yem değeri 50,98-128,59 arasında değişim göstermiştir. IPKPHA4396 oturak tipi, IPKPHA316 sırık tipi, IPKPHA12654 sırık tipi, Manalı Trabzon sırık tipi, IPKPHA7168 sirı tipi ve IPKPHA4398 sirı tipi genotiplerin, araştırmada yer alan diğer genotiplere göre ot verimi ve nispi yem değeri bakımından daha üstün olduğu saptanmıştır.
\end{abstract}

\section{Determination of Using Potentials of Harvest Residues of Some Bean (Phaseolus vulgaris L.) Genotypes as Animal Feed under Continental Climate Conditions}

Keywords NDF and ADF ratio, Crude protein ratio, Bean, Hay yield, Hay quality

\begin{abstract}
This research was established on 18 May 2018 in order to determine forage quality of harvest residues of some bean genotypes grown under conditions of Afşin district of Kahramanmaraş province. A total of 70 different beans (Phaseolus vulgaris L.) were used in the study. The experiment was arranged according to randomized complete block design with three replications. In the research, hay yield, crude protein, crude ash, ADF, NDF ratio and relative feed values were determined. According to the research results; differences among the genotypes studied for the studied characteristics were found statistically significant. Depending on the genotype, dry herbage yield varied between 129.0 and $978.0 \mathrm{~kg} \mathrm{da}^{-1}$, crude protein ratio between 5.65 and14.64\%, crude protein yield between 8.31 and143.63 $\mathrm{kg} \mathrm{da}^{-1}$, crude ash ratio between 5.29 and $28.81 \%$, neutral detergent fibre (NDF) ratio between 48.15 and $80.00 \%$, acid detergent fibre (ADF) ratio between 28.00 and $58.00 \%$ and relative feed value (RFV) between 50.98 and 128.59. In addition, IPKPHA4396, IPKPHA316, IPKPHA12654, Manal1 Trabzon, IPKPHA7168 and IPKPHA4398 genotypes were found to be superior to other genotypes in the study in terms of hay yield and quality.
\end{abstract}

\section{GİRIŞ}

Fasulye (Phaseolus vulgaris L.) dünyada bilinen iki önemli gen merkezine sahip bir bitkidir. $\mathrm{Bu}$ merkezlerden biri, Güney Amerika diğeri ise Orta Amerika bölgesidir. M.Ö. 7000 yıllarında, fasulyenin Meksika'da kültüre alındığı, buradan da İspanyollar tarafindan 16. yüzyılda Avrupa'ya taşındığ bilinmektedir. Ülkemizde hemen hemen her bölgede 
yetiştiriciliği yapılan fasulye yapay ve doğal seleksiyonlarla, ülkemizin diğer bölgelerine yayılma göstererek, bu bölgelerde kendine has isimlerle yeni popülasyonlar meydana gelmiştir [1]. Fasulye insan beslenmesinin yanında, tarım alanlarında toprağın zenginleştirilmesinde önemli bir yere sahiptir. Baklagiller familyasından olan fasulye, köklerinde bulunan ve nodül diye adlandırılan yumrucuklara sahiptir. Bu nodüller nodozite bakterileri (Rhizobium phaseoli) sayesinde havadaki serbest azotu kullanarak toprağın azotça zenginliğini artırmaktadır [2]. Nodozite bakterileri ile bir dekar alanda bir vejetasyon döneminde fasulye bitkisi $3-5 \mathrm{~kg}$ saf azotu toprağa bağlamaktadır [3]. Bu da fasulyeden sonra ekimi yapilacak bitkinin daha az azot gübresi ile yetişmesine imkân sağlamaktadır. Ekilebilir tarım alanlarının azaldığ günümüzde, toprak ve iklim özellikleri göz önüne alındığında ülkemizde hemen hemen her bölgede yetişme özelliğine sahip olan fasulye, tınlı-kumlu topraklarda iyi bir gelişme göstermektedir.

Hayvancılık işletmelerinin kaba yem ihtiyacı farklı kaynaklardan temin edilmektedir. Ülkemizde bu kaynaklardan ilkini 12-15 milyon ton $\mathrm{yl}^{-1}{ }^{1}$ kuru ot elde edilen, biçilerek ve otlatılarak kullanılan 14,6 milyon ha alana sahip çayır ve meralar oluşturmaktadır [4]. Bir diğeri 2,1 milyon ha ekim alanına sahip yem bitkilerinden elde edilen yaklaşı 5,2 milyon ton $\mathrm{yl}^{-1}$ kuru ot ile 547.127 ha ekim alanına sahip silajlık mısırdan elde edilen yaklaşık 26,3 milyon ton $\mathrm{yl}^{-1}{ }^{-1}$ mısır hasilıdır [5]. Yaklaşık 15 milyon ton $\mathrm{yll}^{-1}$ kapasiteye sahip sap, saman gibi tarla atı̆g 1 veya bitkisel atıklar da önemli yem kaynakları arasında yer almaktadır ve maalesef üreticiler tarafindan ana kaba yem kaynağ olarak kullanılmaktadır [6]. Türkiye'de yem bitkileri arasında yaygın olarak yonca, fiğ, mürdümük ve korunga gibi yem bitkilerinin yetiștiriciliği yapılmaktadır. 1 ton tahıl sapında $70,5 \mathrm{~kg}$ protein, 1 ton baklagil sapında ise $137,4 \mathrm{~kg}$ protein bulunmaktadır [7]. Ülkemizdeki hayvancılık faaliyetlerine bakıldığında kaliteli kaba yem açığı olduğu, bu açığın ise hayvan beslemede farklı protein değerlerine sahip buğdaygil ve baklagil hasat artıkları ile giderilmeye çalışıldığı görülmektedir. Bunlar arasında özellikle protein değeri çok düşük $(\% 3,5)$ olan buğday samanı hala yaygın olarak kullanılmaktadır. Sap ve samanlarındaki protein oranının tahılların iki katına yakın olmasından dolayı, hayvan beslenmesinde kaba yem ve kesif yem ihtiyacının karşılanmasında, baklagiller önemli bir yere sahiptir. Fasulye tarımı yapan çiftçiler ve hayvancılık işletmeleri ile yapılan görüşmeler neticesinde özellikle küçükbaş hayvancılık yapılan işletmelerde proteince zengin kaba yemlerin işletmeye alınamadığ 1 ve yem bitkilerine alternatif olan fasulye samanının ön plana çıktığı saptanmıştır. Fasulye bitkisi özellikle danesi için yetiştirilen bir baklagildir. Birçok buğdaygil ve baklagil bitki türünün hayvan beslemede kullanmak üzere silaj olarak kullanıldığını ifade eden Uslu ve Kaya [8], bu bitkiler arasında fasulyeyi zikretmemiştir. Fasulye, samanı ile öne çıkan alternatif bir kaba yem kaynağıdır. Fasulye hasat artıklarının kimyasal kompozisyonunu gösteren ve sayısı çok az olan bir kaç araştırmada NDF, ADF ve sindirilebilir kuru madde (SKM) oranlarının sırası ile \%51-69, \%37,3-56,5 ve \%53-59 arasında olduğu bildirilmiştir [9-10-11-12]. Ayrıca yerfistığı, mercimek ve börülce gibi bazı diğer baklagillerin genotip ve çevreye bağlı olarak otlarının kimyasal bileşiminde ve sindirilebilirliğinde önemli farkl11ıklar olduğu bildirilmiştir [13-14-15-16]. Mesela Erskine et al. [13] mercimek otunun sindirilebilir kuru maddenin \%40-49, ham protein oranın \%5,8-6,9 arasında değiş̧tiğini saptamışlardır. Ülkemizde fasulye hasat artıklarının yem değeri hakkında bir araştırmaya rastlanmamıştır.

Fasulye tarımında 2018 yılı verilerine göre Türkiye genelinde yedinci sırada yer alan Kahramanmaraş ilinde özellikle Afşin ve çevresinde geniş alanlarda fasulye tarımı yapılmaktadır. Hasattan sonra geriye kalan otunun, hayvancılık yapan çiftçiler tarafindan yoğun bir talep gördüğü ve hatta talebin karşılanamadığı işletme sahipleri tarafindan ifade edilmektedir. Uslu ve ark. [17] Kahramanmaraş'ta 335.126 ton $\mathrm{yll}^{-1}$ kaba yem üretildiğini, bu miktarın toplam kaba yem ihtiyacının \%36,16'sını karșıladığını ve ilin mevcut hayvan varlığı için 926.874 ton $\mathrm{yll}^{-1}$ kaba yeme ihtiyaç olduğunu bildirmişlerdir. $\mathrm{Bu}$ açığın kapatılmasında mevcut yem bitkileri üretimine ilaveten alternatif yem kaynaklarının yardımcı olması mümkündür. Bu çalışma, Türkiye'de önemli fasulye üretim merkezi olan Afşin şartlarında, tane hasadından sonra hasat artığı olan fasulye vejetatif aksamının alternatif kaba yem kaynağı olarak hayvan besleme potansiyelini belirlemek üzere yapılmıştır.

\section{MATERYAL VE METOT}

\subsection{Araştırma Yeri ve Yılı}

Bu çalışma ile ilgili tarla denemesi 2018 yaz üretim sezonunda, Kahramanmaraş İli, Afşin İlçesi Çobanbeyli Mahallesi Keçebey Mevkiinde 18 Mayıs 2018 tarihinde kurulmuştur. Akdeniz Bölgesinin Doğu Anadolu ve Orta Anadolu Bölgelerine geçit alanında $38^{\circ} 21^{\prime} 18.53^{\prime \prime}$ kuzey enlem ve $36^{\circ} 53^{\prime} 58.12 "$ doğu boylam dereceleri arasında yer alan deneme alanı \%1-2 eğime sahip olup deniz seviyesinden yüksekliği 1243 m'dir.

\subsection{Bitki Materyali}

Araştırma materyali olarak 40 sırık ve 30 oturak olmak üzere 70 fasulye genotipi materyal olarak kullanılmıştır. $\mathrm{Bu}$ genotiplerin tamamı Kahramanmaraş Sütçü İmam Üniversitesi Ziraat Fakültesi Tarla Bitkileri Bölümü öğretim üyesi Dr. Öğr. Üyesi Cengiz Yürürdurmaz tarafından USDA'dan (ABD Tarım Bakanlığı) 2016 yllında temin edilmiştir.

\subsection{Araştırma Alanının İklim ve Toprak Özellikleri}

Afşin coğrafi alan olarak Doğu Anadolu bölgesinin yukarı Fırat bölümünün en batı kesiminde yer almaktadır. Afşin ve çevresi Akdeniz bölgesi, Orta Anadolu ve Doğu Anadolu bölgelerinin birbirine en çok yaklaştığı, dolayısıyla değişik iklim özelliklerine sahip bölgelerinin kesiştiği ve $1242 \mathrm{~m}$ yüksekliği olan bir alanda bulunmaktadır. Araştırmanın yapıldığı 2018 ürün 
yıllı ile uzun yıllar ortalamasina ait bazı iklim verileri Tablo 1'de verilmiştir [18].

Çalışma alanı tipik karasal iklim özellikleri göstermektedir. Araştırmanın yürütüldüğü dönemde uzun yıllar ortalamalarına göre Kahramanmaraș Afșin'de $11,3{ }^{\circ} \mathrm{C}$ aylık ortalama sıcaklık ile en soğuk ayın Nisan olduğu, en sicak ayın ise $24,9{ }^{\circ} \mathrm{C}$ ile Ağustos olduğu kaydedilmiştir. 2018 yllında ise en soğuk ay $13,0{ }^{\circ} \mathrm{C}$ ile yine Nisan, en sicak ay ise $25,2{ }^{\circ} \mathrm{C}$ ile Temmuz ayıdır. 2018 yılı yetiştirme sezonunda uzun yıllar ortalamasından $(147,1 \mathrm{~mm})$ daha fazla miktarda yağış $(153,4 \mathrm{~mm})$ kaydedilirken Temmuz ve Ağustos aylarında hiç yağış olmamıștır. 2018 yılı nispi nem ortalamas1 da $(\% 44,1)$ uzun y1lar ortalamasindan $(\% 43,8)$ daha yüksektir (Tablo 1) [18].

Tablo 1. Araştırma dönemine ait bazı iklim verileri.

\begin{tabular}{lllcccc}
\hline Aylar & \multicolumn{2}{c}{$\begin{array}{c}\text { Toplam Yağıș } \\
(\mathbf{m m})\end{array}$} & \multicolumn{2}{c}{$\begin{array}{c}\text { Ortalama } \\
\text { Sicaklık } \\
\left({ }^{\circ} \mathbf{C}\right)\end{array}$} & $\begin{array}{c}\text { Ortalama Nispi } \\
\text { Nem } \\
(\%)\end{array}$ \\
\cline { 2 - 7 } & $\mathbf{2 0 1 8}$ & $\begin{array}{c}\text { Uzun } \\
\text { Yıllar }\end{array}$ & $\mathbf{2 0 1 8}$ & $\begin{array}{c}\text { Uzun } \\
\text { Yıllar }\end{array}$ & $\mathbf{2 0 1 8}$ & $\begin{array}{c}\text { Uzun } \\
\text { Yıllar }\end{array}$ \\
\hline Nisan & 12,2 & 48,7 & 13,0 & 11,3 & 45,2 & 53,2 \\
Mayıs & 109,0 & 47,2 & 15,8 & 15,0 & 61,2 & 57,7 \\
Haziran & 17,6 & 16,9 & 20,4 & 20,3 & 51,7 & 46,1 \\
Temmuz & 0,0 & 16,4 & 25,2 & 24,7 & 36,6 & 33,7 \\
Ağustos & 0,0 & 4,4 & 24,8 & 24,9 & 33,2 & 33,6 \\
Eylül & 14,6 & 13,4 & 20,8 & 20,4 & 36,2 & 38,6 \\
\hline Top./Ort. & 153,4 & 147,1 & 11,33 & 19,4 & 44,1 & 43,8 \\
\hline
\end{tabular}

Deneme alanında $0-30 \mathrm{~cm}$ derinlikten alınan toprak örneklerinin Sivas Şarkışla Toprak Analiz Merkezinde yapılan analiz sonuçlarına göre, deneme alanı toprakları; killi tınlı $(62,26)$, tuzsuz $(\% 3)$, orta kireçli $(\% 3,05)$, organik madde bakımından orta seviyede $(\% 2,08)$, potasyum oranı yeterlilik seviyesinin üzerinde $(77,8 \mathrm{mg}$ $\left.\mathrm{kg}^{-1}\right)$ ve fosfor bakımından orta $\left(8,46 \mathrm{mg} \mathrm{kg} \mathrm{kg}^{-1}\right)$ seviyededir [19].

\subsection{Metot}

Araştırma ile ilgili tarla denemesi üç tekrarlamalı tesadüf blokları deneme desenine göre yürütülmüsstür. Ekim, 50 $\mathrm{cm}$ sıra aralığı ile açılan $2 \mathrm{~m}$ uzunluğundaki sıralara, her sıraya 10 tohum gelecek şekilde elle ve tek sira olarak yapılmıştır. Ekim öncesinde tarla sonbaharda derin olarak sürülmüş, Nisan ayına kadar bekletilmiştir. Ekimden önce besin maddesi ihtiyacı toprak analiz sonuçlarına göre $7 \mathrm{~kg} \mathrm{da}^{-1}$ saf azot ve $7 \mathrm{~kg} \mathrm{da}^{-1}$ saf fosfora isabet edecek şekilde 20.20.0 kompoze taban gübresi uygulanarak tamamlanmıştır. Yetiştirme süresince tarlada sulama, çapalama ve gerekli diğer bakım işlemleri yapılmış olup, deneme alanına damlama sulama sistemi kurularak 8 defa, her sulamada 7 saat esas alınarak sulama yapılmıștır. Hasat 8-15 Eylül 2018 tarihleri arasında elle yapılmıştır.

\subsection{Yapılan Gözlem ve Ölçümler}

Araştırmada kuru ot verimi, ham protein oranı, ham protein verimi, ham kül oranı, nötr deterjan lif oranı, asit deterjan lif oranı nispi yem değeri özellikleri; Kaçar [20], Van Soest et al. [21], Sheaffer et al. [22], Parlak [23], Kutlu [24], Anonim [25] tarafindan tarif edilen yöntemlere göre incelenmiștir. Parseldeki tüm bitkiler hasat edildikten sonra kurutulmuş, taneler alındıktan sonra kalan hasat artıkları tartılmış ve dekara kuru ot verimi $\mathrm{kg} \mathrm{da}^{-1}$ olarak hesaplanmıştır. Kurutulmuş bitki örnekleri ögütülerek $1 \mathrm{~mm}$ elekten geçirilmiş ve analize hazır hale getirilmiștir. Öğütülen ot örneklerinde Kjeldahl yöntemi ile azot analizi yapılmıştır. Saptanan azot içeriği değerleri daha sonra 6.25 katsayısı ile çarpılmış, her örneğe ait ham protein içeriği belirlenmiștir. Parselin ham protein oranı parsele ait kuru ot verimi ile çarpılmış ve ham protein verimi belirlenmiş daha sonra gerekli dönüşümler yapılmış ham protein verimi $\mathrm{kg} \mathrm{da}^{-1}$ cinsinden hesaplanmıștır. Ham kül oranı belirlenmesinde $105{ }^{\circ} \mathrm{C}$ 'de kurutulan ve desikatörde soğutulan ot numunelerinden temin edilen 3 'er gramlık örnekler, porselen krozeye yerleştirilerek $550{ }^{\circ} \mathrm{C}$ 'de 3 saat süreyle yakılmıştır. Elde edilen kül yakılan örneğe oranlanarak ham kül oranı hesaplanmıștır. Nötr ortamda çözünmeyen lif (NDF) ve asitli ortamda çözünmeyen lif (ADF) içerikleri ANKOM filtre torbası tekniği kullanılarak ANKOM A220 lif analiz cihazı (ANKOM Teknoloji, Fairport, NY) vasıtasıyla belirlenmiştir. Sindirilebilir kuru madde (SKM) değeri, kuru madde tüketimi (KMT) değeri ve nispi yem değeri (NYD) NDF ve ADF analiz sonuçları değerlendirilerek Eşitlik 1, 2 ve 3 kullanılarak hesaplanmıștır.

$$
\begin{aligned}
& \mathrm{SKM}=88,9-(0,779 \times \% \text { ADF }) \\
& \mathrm{KMT}=120 / \% \mathrm{NDF} \text { (kuru maddede }) \\
& \mathrm{NYD}=(\mathrm{SKM} \times \mathrm{KMT}) / 1,29
\end{aligned}
$$

\subsection{Verilerin Değerlendirilmesi}

Araştırma sonucunda elde edilen veriler, SAS [26] programı kullanılarak, tesadüf blokları deneme desenine göre varyans analizine tabi tutulmuştur. Varyans analiz sonuçlarına göre istatiksel olarak önemli bulunan özelliklere ilişkin ortalamalar arasındaki farklar Tukey testi ile karşılaştırılmıştır [27]

\section{BULGULAR}

\subsection{Kuru Ot Verimi $\left(\mathrm{kg} \mathrm{da}^{-1}\right)$}

Fasulye genotiplerine ait kuru ot verimi değerlerine ilişkin ortalamalar ve oluşan gruplar Tablo 2'de verilmiştir. Tablo 2'ye göre, genotiplere ait kuru ot verimi ortalama değerleri 129,7-978,0 $\mathrm{kg} \mathrm{da}^{-1}$ arasında değişim göstermiştir. En yüksek kuru ot verimi ortalamas1 Manal1 Trabzon genotipinde $978,0 \mathrm{~kg} \mathrm{da}^{-1}$ olarak saptanırken bunu $672,3 \mathrm{~kg} \mathrm{da}^{-1}$ ile IPKPHA7168 genotipi, $665 \mathrm{~kg} \mathrm{da}^{-1}$ ile IPKPHA4398 genotipi takip etmiş, en düşük kuru ot verimi ortalaması ise IPKPHA4386 genotipinde $129,7 \quad \mathrm{~kg} \quad \mathrm{da}^{-1}$ olarak saptanmıştır.

Ülkemizde daha önce fasulyede hasat artığı verimi ile ilgili bir araştırma yapılmadı $\breve{g}$ için bu araştırmada saptanan kuru ot verimi değerleri ot amacıyla yetiştirilen bir baklagil bitkisi olan fiğ bitkisinde saptanan kuru ot verimleri ile karşılaştırılmıștır. Fiğde, Çil ve ark.'nın [28] farklı iklim özelliklerinde 356-479 $\mathrm{kg} \mathrm{da}^{-1}$, Zeybek'in [29] Tekirdağ'da 552,3 $\mathrm{kg} \mathrm{da}^{-1}$, Kara ve 
Çomaklı'nın [30] Erzurum'da 216,1-274,2 kg da ${ }^{-1}$, Önder'in [31] Tokat'ta 320-432 kg da ${ }^{-1}$, Seydoşoğlu'nun [32] Diyarbakır'da 308,0-919,5 kg da ${ }^{-1}$, Erdoğdu ve ark.'nın [33] Eskişehir'de $633 \mathrm{~kg} \mathrm{da}^{-1}$, Eviz ve ark.'nın [34] Siirt'te 222-395 kg da ${ }^{-1}$, Budak'ın [35] Iğdır'da $644,7-741,3 \mathrm{~kg} \mathrm{da}^{-1}$ olarak saptadıkları fiğ kuru ot verimi değerleri bu araştırmada saptanan fasulye kuru ot verimi değerleri ile benzerlik göstermektedir. Dejenea et al. [36] Etiyopya'da fasulye hasat artığ 1 verimini $52-336 \mathrm{~kg} \mathrm{da}^{-1}$
Akınc1 [37] ise Kayseri'de soya fasulyesinde 247,71$357,90 \mathrm{~kg} \mathrm{da}^{-1}$ kuru ot verimi saptamıştır. Araştırmamızda bazı genotiplerde saptanan fasulye kuru ot verimi değerleri söz konusu araştırmalarda saptanan fasulye kuru ot verimi ve soya fasulyesi kuru ot verimi değerlerinden oldukça yüksektir. Bulgulardaki farklılıkların ekim normu ve ekolojik farklılıklardan kaynaklandığı söylenebilir.

Tablo 2. Fasulye genotiplerinin kuru ot verimi $\left(\mathrm{kg} \mathrm{da}^{-1}\right)$ ortalamaları ve oluşan gruplar.

\begin{tabular}{|c|c|c|c|c|c|}
\hline Genotipler & Tipi & Ortalama & Genotipler & Tipi & Ortalama \\
\hline Artvin barbunya & Sirık & 269,0 b-g* & Rize-1 & Sirık & $386,3 \mathrm{~b}-\mathrm{g}$ \\
\hline Çubuk Trabzon & Sirık & $328,7 \mathrm{~b}-\mathrm{g}$ & Rize-2 & Sirık & 553,7 a-g \\
\hline IPKPHA429 & Sirık & $520,3 \mathrm{~b}-\mathrm{g}$ & Çalı & Sirık & $544,0 \mathrm{~b}-\mathrm{g}$ \\
\hline BVAL610697 & Sirık & $516,7 \mathrm{~b}-\mathrm{g}$ & IPKPHA4803 & Sirık & $640,3 \mathrm{a}-\mathrm{c}$ \\
\hline Rize-8 & Sirık & $520,7 \mathrm{~b}-\mathrm{g}$ & Eskişehir taze & Sirık & $353,0 \mathrm{~b}-\mathrm{g}$ \\
\hline Rize-5 & Sirık & 626,0 a-d & IPKPHA4785 & Oturak & $237,0 \mathrm{c}-\mathrm{g}$ \\
\hline IPKPHA4378 & Sirık & $306,3 \mathrm{~b}-\mathrm{g}$ & IPKPHA5021 & Oturak & $286,0 \mathrm{~b}-\mathrm{g}$ \\
\hline IPKPHA169761 & Sirık & $546,3 \mathrm{~b}-\mathrm{g}$ & IPKPHA4739 & Oturak & $190,7 \mathrm{e}-\mathrm{g}$ \\
\hline IPKPHA4716 & Sirık & $537,3 \mathrm{~b}-\mathrm{g}$ & IPKPHA4396 & Oturak & $385,7 \mathrm{~b}-\mathrm{g}$ \\
\hline Ayşekadınçalıyaçıkan & Sirık & $289,7 \mathrm{~b}-\mathrm{g}$ & Siyah fasulye & Oturak & $372,7 \mathrm{~b}-\mathrm{g}$ \\
\hline Ayşekadın & Sirık & $544,0 \mathrm{~b}-\mathrm{g}$ & IPKPHA177045 & Oturak & $180,0 \mathrm{e}-\mathrm{g}$ \\
\hline IPKPHA316 & Sirık & $440,0 \mathrm{~b}-\mathrm{g}$ & IPKPHA494 & Oturak & $159,7 \mathrm{fg}$ \\
\hline IPKPHA12654 & Sirık & $443,3 \mathrm{~b}-\mathrm{g}$ & Trabzon barbun & Oturak & $382,3 \mathrm{~b}-\mathrm{g}$ \\
\hline Basara çalı & Sirık & 491,0 b-g & Yerli 40 günlük & Oturak & $239,0 \mathrm{c}-\mathrm{g}$ \\
\hline Rize-10 & Sirık & $548,7 \mathrm{~b}-\mathrm{g}$ & IPKPHA5017 & Oturak & 369,3 b-g \\
\hline IPKРHA4779 & Sirık & $5680 \mathrm{a}-\mathrm{f}$ & Kanton & Oturak & 209,7 d-g \\
\hline IPKPHA4398 & Sirık & $665,7 \mathrm{ab}$ & Mecidiye & Oturak & $335,7 \mathrm{~b}-\mathrm{g}$ \\
\hline Adana taze & Sirık & 575,3 a-f & IPKPHA4721 & Oturak & 304,3 b-g \\
\hline IPKPHA4815 & Sirık & $416,3 \mathrm{~b}-\mathrm{g}$ & IPKPHA5011 & Oturak & $270,3 \mathrm{~b}-\mathrm{g}$ \\
\hline IPKPHA4992 & Sirık & $513,0 \mathrm{~b}-\mathrm{g}$ & Mercan & Oturak & $237,0 \mathrm{c}-\mathrm{g}$ \\
\hline Manalı Trabzon & Sirık & $978,0 \mathrm{a}^{\circ}$ & Önceler 98 & Oturak & $308,7 \mathrm{~b}-\mathrm{g}$ \\
\hline IPKPHA12651 & Sirık & $501,3 \mathrm{~b}-\mathrm{g}$ & IPKPHA4386 & Oturak & $129,7 \mathrm{fg}$ \\
\hline IPKPHA131 & Sirık & 340,0 b-g & Barbunya & Oturak & $248,0 \mathrm{~b}-\mathrm{g}$ \\
\hline Rize-6 & Sirık & 617,3 a-d & IPKPHA13761 & Oturak & 291,0 b-g \\
\hline IPKPHA5002 & Sirık & $247,7 \mathrm{~b}-\mathrm{g}$ & IPKPHA12763 & Oturak & $312,7 \mathrm{~b}-\mathrm{g}$ \\
\hline IPKPHA12675 & Sirık & 569,0 a-f & IPKPHA4445 & Oturak & $217,7 \mathrm{c}-\mathrm{g}$ \\
\hline IPKPHA4384 & Sirık & $464,3 \mathrm{~b}-\mathrm{g}$ & IPKPHA4972 & Oturak & $259,3 \mathrm{~b}-\mathrm{g}$ \\
\hline IPKPHA7167 & Sirık & $482,3 \mathrm{~b}-\mathrm{g}$ & IPKPHA4402 & Oturak & $260,3 \mathrm{~b}-\mathrm{g}$ \\
\hline IPKPHA241 & Sirık & 313,0 b-g & Yağlı fasulye & Oturak & 296,7 b-g \\
\hline Peru & Sirık & $553,3 \mathrm{a}-\mathrm{g}$ & IPKPHA4773 & Oturak & 319,3 b-g \\
\hline IPKPHA7168 & Sirık & $672,3 \mathrm{ab}$ & IPKPHA4981 & Oturak & $272,3 \mathrm{~b}-\mathrm{g}$ \\
\hline IPKPHA132 & Sirık & 339,0 b-g & IPKPHA5001 & Oturak & 291,3 b-g \\
\hline Aksaray ihlara & Sirık & $560,7 \mathrm{a}-\mathrm{f}$ & IPKPHA4414 & Oturak & $415,0 \mathrm{~b}-\mathrm{g}$ \\
\hline IPKPHA12671 & Sirık & $502,3 \mathrm{~b}-\mathrm{g}$ & IPKPHA4736 & Oturak & $236,0 \mathrm{c}-\mathrm{g}$ \\
\hline Yer & Sirık & 605,0 a-e & Yakutiye & Oturak & $377,7 \mathrm{~b}-\mathrm{g}$ \\
\hline
\end{tabular}

\subsection{Ham Protein Oranı (\%)}

Fasulye genotiplerine ait kuru ot ham protein oranı değerlerine ilişkin ortalamalar ve oluşan gruplar Tablo 3 'te verilmiştir. Genotiplere ait kuru ot ham protein oranı ortalama değerleri \%5,65-\%14,64 arasında değişim göstermiştir (Tablo 3). En yüksek ham protein oranı ortalaması Manalı Trabzon genotipinde \%14,64 olarak saptanırken bunu \%12,86 ile IPKPHA4398 genotipi, \%12,52 ile IPKPHA7168 genotipi takip etmiş, en düşük kuru ot ham protein oranı ortalaması ise Mecidiye genotipinde $\% 5,65$ olarak saptanmıştır.

Güngör ve ark. [38] kaba yemlerin ham protein oranını KM bazında; yonca kuru otlarında \%11,44-20,79, misır silajinda \%5,08-6,33, kuru misir hasilinda \%3,00-4,47, üzüm cibresinde ise $\% 11,34-12,59$, olarak saptamışlardır. Açıkgöz ve ark. [39] Bursa'da soya fasulyesi kuru otunda ham protein oranını \%16,8, Kökten ve ark. [40] yerfistığı kuru otunda ham protein oranını \%6,15-10.11, Macar fiği kuru otunda ham protein oranını Kara ve Çomaklı [30] \%17,0-20,0, Eviz ve ark. [34] \%22,27, Budak [35] \%18,87-20,05, Hashalıcı ve ark. [41] \%16,0-18,6 olarak saptamışlardır. Uslu ve Gedik [42] Kahramanmaraş'ta anason kuru otunda ham protein oranını \%14,92-15,79, Akınc1 [37] Kayseri'de soya fasulyesi kuru otunda \%6,66-13,53, Uslu ve ark. [43] Kahramanmaraş'ta yemlik bakla kuru otunda \%12,24 ve yemlik bezelye kuru otunda \%13,99 olarak bildirmişlerdir. Farklı araştırmalarda farklı bitkilerde ham protein oranı değerlerinin saptanmasına sebep olarak, bitki türü, araştırmaların yürütüldüğü ekolojik koşullar, incelenen genotipler ve uygulanan yetiştirme teknikleri (bitki sıklığı, sulama ve gübreleme) arasındaki farklılıklar gösterilebilir. Fasulye genotiplerinin hasat artıklarında saptanan ham protein oranları çeltik $(\% 2,76)$ ve buğday $(\% 3)$ samanı ve kuru misır hasılının ham protein oranından daha yüksek olarak belirlenmiştir [38-44-45]. 
Tablo 3. Fasulye genotiplerinin kuru otlarında saptanan ham protein oranı (\%) ortalamaları ve oluşan gruplar.

\begin{tabular}{|c|c|c|c|c|c|}
\hline Genotipler & Tipi & Ortalama & Genotipler & Tipi & Ortalama \\
\hline Artvin barbunya & Sirık & $8,85 \mathrm{p}-\mathrm{t}^{*}$ & Rize-1 & Sirık & 9,83 k-p \\
\hline Çubuk Trabzon & Sirık & $8,88 \mathrm{p}-\mathrm{t}$ & Rize-2 & Sirık & 9,88 1-p \\
\hline IPKPHA429 & Sirık & $8,86 \mathrm{p}-\mathrm{t}$ & Çalı & Sirık & $10,76 \mathrm{f}-\mathrm{m}$ \\
\hline BVAL610697 & Sirık & $9,48 \mathrm{n}-\mathrm{r}$ & IPKPHA4803 & Sirık & $8,30 \mathrm{r}-\mathrm{v}$ \\
\hline Rize-8 & Sirık & $9,41 \mathrm{n}-\mathrm{r}$ & Eskişehir taze & Sirık & $9,42 \mathrm{n}-\mathrm{r}$ \\
\hline Rize-5 & Sirık & $10,92 \mathrm{f}-\mathrm{k}$ & IPKPHA4785 & Oturak & $8,56 \mathrm{r}-\mathrm{u}$ \\
\hline IPKPHA4378 & Sirık & $9,64 \mathrm{~m}-\mathrm{q}$ & IPKPHA5021 & Oturak & $6,54 \mathrm{a}-\mathrm{z}$ \\
\hline IPKPHA169761 & Sirık & $10,33 \mathrm{~h}-\mathrm{o}$ & IPKPHA4739 & Oturak & $6,14 a b$ \\
\hline IPKPHA4716 & Sirık & 10,04 1-p & IPKPHA4396 & Oturak & $7,87 \mathrm{~s}-\mathrm{w}$ \\
\hline Ayşekadınçalıyaçıkan & Sirık & $11,85 \mathrm{~b}-\mathrm{f}$ & Siyah fasulye & Oturak & $7,92 \mathrm{~s}-\mathrm{w}$ \\
\hline Ayşekadın & Sirık & $10,91 \mathrm{f}-1$ & IPKPHA 177045 & Oturak & 9,18 o-r \\
\hline IPKPHA316 & Sirık & $11,30 \mathrm{c}-\mathrm{h}$ & IPKPHA494 & Oturak & $10,77 \mathrm{f}-\mathrm{m}$ \\
\hline IPKPHA 12654 & Sirık & $11,27 \mathrm{f}-\mathrm{h}$ & Trabzon barbun & Oturak & 7,15 a-z \\
\hline Basara çalı & Sirık & $9,26 \mathrm{n}-\mathrm{r}$ & Yerli 40 günlük & Oturak & $7,41 \mathrm{u}-\mathrm{z}$ \\
\hline Rize-10 & Sirık & $11,46 \mathrm{c}-\mathrm{h}$ & IPKPHA5017 & Oturak & $7,73 \mathrm{t}-\mathrm{x}$ \\
\hline IPKPHA4779 & Sirık & 9,89 1-p & Kanton & Oturak & $7,14 \mathrm{a}-\mathrm{z}$ \\
\hline IPKPHA4398 & Sirık & $12,86 \mathrm{~b}$ & Mecidiye & Oturak & $5,65 \mathrm{~b}$ \\
\hline Adana taze & Sirık & $10,97 \mathrm{f}-\mathrm{k}$ & IPKPHA4721 & Oturak & $7,50 u-y$ \\
\hline IPKPHA4815 & Sirık & $9,80 \mathrm{k-p}$ & IPKPHA5011 & Oturak & $6,41 \mathrm{a}-\mathrm{z}$ \\
\hline IPKPHA4992 & Sirık & $9,87 \mathrm{k}-\mathrm{p}$ & Mercan & Oturak & $6,81 \mathrm{a}-\mathrm{z}$ \\
\hline Manalı Trabzon & Sirık & $14,64 \mathrm{bc}$ & Önceler 98 & Oturak & $6,23 \mathrm{a}-\mathrm{z}$ \\
\hline IPKPHA12651 & Sirık & $11,69 \mathrm{~b}-\mathrm{g}$ & IPKPHA4386 & Oturak & $6,47 \mathrm{a}-\mathrm{z}$ \\
\hline IPKPHA131 & Sirık & $11,05 e-j$ & Barbunya & Oturak & $9,06 \mathrm{p}-\mathrm{s}$ \\
\hline Rize-6 & Sirık & $11,83 \mathrm{~b}-\mathrm{f}$ & IPKPHA13761 & Oturak & 9,16 o-r \\
\hline IPKPHA5002 & Sirık & $9,701-q$ & IPKPHA12763 & Oturak & $7,23 \mathrm{a}-\mathrm{z}$ \\
\hline IPKPHA12675 & Sirık & $12,25 \mathrm{~b}-\mathrm{e}$ & IPKPHA4445 & Oturak & $9,53 n-q$ \\
\hline IPKPHA4384 & Sirık & 9,18 o-r & IPKPHA4972 & Oturak & $7,83 \mathrm{t}-\mathrm{w}$ \\
\hline IPKPHA7167 & Sirık & $8,85 \mathrm{p}-\mathrm{t}$ & IPKPHA4402 & Oturak & $6,76 \mathrm{a}-\mathrm{z}$ \\
\hline IPKPHA241 & Sirık & $7,75 \mathrm{t}-\mathrm{x}$ & Yağlı fasulye & Oturak & $6,42 \mathrm{a}-\mathrm{z}$ \\
\hline Peru & Sirık & 10,48 g-n & IPKPHA4773 & Oturak & $7,72 \mathrm{t}-\mathrm{x}$ \\
\hline IPKPHA7168 & Sirık & $15,52 \mathrm{a}$ & IPKPHA4981 & Oturak & $11,09 \mathrm{e}-1$ \\
\hline IPKPHA132 & Sirık & $12,39 \mathrm{~b}-\mathrm{d}$ & IPKPHA5001 & Oturak & $7,90 \mathrm{~s}-\mathrm{w}$ \\
\hline Aksaray ihlara & Sirık & $11,83 \mathrm{~b}-\mathrm{f}$ & IPKPHA4414 & Oturak & $10,28 \mathrm{~h}-\mathrm{o}$ \\
\hline IPKPHA12671 & Sirık & 11,08 e-j & IPKPHA4736 & Oturak & $10,32 \mathrm{~h}-\mathrm{o}$ \\
\hline Yer & Sirık & $12,42 \mathrm{~b}-\mathrm{d}$ & Yakutiye & Oturak & $6,39 \mathrm{a}-\mathrm{z}$ \\
\hline
\end{tabular}

*) Benzer harf ile gösterilen genotip ortalamaları Tukey testine göre $\mathrm{P} \leq 0,05$ hata sınırları içerisinde birbirinden farksızdır.

\subsection{Ham Protein Verimi $\left(\mathrm{kg} \mathrm{da}^{-1}\right)$}

Fasulye genotiplerinin hasat artıkları ile ilgili ham protein verimi değerlerine ilişkin ortalamalar ve oluşan gruplar Tablo 4'te verilmiştir. Genotiplere ait ham protein verimi ortalama değerleri $8,31-143,63 \mathrm{~kg} \mathrm{da}^{-1}$ arasında değișim göstermiștir (Tablo 4). En yüksek ham protein verimi ortalamas1 Manalı Trabzon genotipinde $143,63 \mathrm{~kg} \mathrm{da}^{-1}$ olarak saptanırken bunu $84,77 \mathrm{~kg} \mathrm{da}^{-1}$ ile IPKPHA4398 genotipi, 84,17 $\mathrm{kg} \mathrm{da}^{-1}$ ile IPKPHA7168 genotipi izlemiş, en düşük ham protein verimi ortalaması ise IPKPHA4386 genotipinde $8,31 \mathrm{~kg} \mathrm{da}^{-1}$ olarak saptanmıştır.
Zeybek [29] fiğgde Tekirdağ koşullarında ham protein verimini $111,5 \mathrm{~kg} \mathrm{da}^{-1}$, Acar ve Mülayim [46] Konya'da 60,5 $\mathrm{kg} \mathrm{da}^{-1}$, Yılmaz ve ark. [47] Doğu Akdeniz'de 112 $\mathrm{kg} \mathrm{da}^{-1}$, Çaçan ve ark. [48] Bingöl'de 21,2-37,3 $\mathrm{kg} \mathrm{da}^{-1}$, Hashalıc1 ve ark. [41] Kayseri'de 70,8-130,1 kg da', yem bezelyesinde Kara ve Çomaklı [30] Erzurum'da $37,9-53,4 \mathrm{~kg} \mathrm{da}{ }^{-1}$, soya fasulyesinde Akınc1 [37] Kayseri'de 16,91-39,86 kg da ${ }^{-1}$ olarak saptamıştır. 
Tablo 4. Fasulye genotiplerinin kuru ot ham protein verimi $\left(\mathrm{kg} \mathrm{da}^{-1}\right)$ ortalamaları ve oluşan gruplar.

\begin{tabular}{|c|c|c|c|c|c|}
\hline Genotipler & Tipi & Ortalama & Genotipler & Tipi & Ortalama \\
\hline Artvin barbunya & Sirık & $23,83 \mathrm{f}-1^{*}$ & Rize-1 & Sirık & $37,97 \mathrm{c}-1$ \\
\hline Çubuk Trabzon & Sirık & $29,20 \mathrm{~d}-1$ & Rize-2 & Sirık & $54,83 \mathrm{~b}-\mathrm{k}$ \\
\hline IPKPHA429 & Sirık & 46,18 b-1 & Çalı & Sirık & $58,26 \mathrm{~b}-\mathrm{j}$ \\
\hline BVAL610697 & Sirık & 48,93 b-1 & IPKPHA4803 & Sirık & $55,94 \mathrm{~b}-\mathrm{k}$ \\
\hline Rize-8 & Sirık & 49,02 b-1 & Eskişehir taze & Sirık & $33,15 \mathrm{c}-1$ \\
\hline Rize-5 & Sirık & $68,08 \mathrm{~b}-\mathrm{f}$ & IPKPHA4785 & Oturak & $20,30 \mathrm{~h}-1$ \\
\hline IPKPHA4378 & Sirık & $29,44 \mathrm{~d}-1$ & IPKPHA5021 & Oturak & $18,691-1$ \\
\hline IPKPHA169761 & Sirık & $56,47 \mathrm{~b}-\mathrm{j}$ & IPKPHA4739 & Oturak & $11,72 \mathrm{kl}$ \\
\hline IPKPHA4716 & Sirık & $54,03 \mathrm{~b}-\mathrm{k}$ & IPKPHA4396 & Oturak & $30,52 \mathrm{~d}-1$ \\
\hline Ayşekadınçalıyaçıkan & Sirık & $34,30 \mathrm{c}-1$ & Siyah fasulye & Oturak & $29,56 \mathrm{~d}-1$ \\
\hline Ayşekadın & Sirık & $59,29 \mathrm{~b}-\mathrm{j}$ & IPKPHA177045 & Oturak & $16,55 \mathrm{j}-1$ \\
\hline IPKPHA316 & Sirık & $49,70 \mathrm{~b}-1$ & IPKPHA494 & Oturak & $17,38 \mathrm{j}-1$ \\
\hline IPKPHA 12654 & Sirık & $50,54 \mathrm{~b}-1$ & Trabzon barbun & Oturak & 27,35 e-1 \\
\hline Basara çalı & Sirık & $45,65 \mathrm{~b}-1$ & Yerli 40 günlük & Oturak & $17,69 \mathrm{j}-1$ \\
\hline Rize-10 & Sirık & $62,73 \mathrm{~b}-1$ & IPKPHA5017 & Oturak & $28,54 \mathrm{e}-1$ \\
\hline IPKPHA4779 & Sirık & $56,19 \mathrm{~b}-\mathrm{j}$ & Kanton & Oturak & $15,07 \mathrm{j}-1$ \\
\hline IPKPHA4398 & Sirık & $84,77 \mathrm{~b}$ & Mecidiye & Oturak & $19,07 \mathrm{~h}-1$ \\
\hline Adana taze & Sirık & $63,11 \mathrm{~b}-\mathrm{h}$ & IPKPHA4721 & Oturak & $22,83 \mathrm{~g}-1$ \\
\hline IPKPHA4815 & Sirık & 40,46 b-1 & IPKPHA5011 & Oturak & $17,34 \mathrm{j}-1$ \\
\hline IPKPHA4992 & Sirık & $50,63 \mathrm{~b}-1$ & Mercan & Oturak & $16,15 \mathrm{j}-1$ \\
\hline Manalı Trabzon & Sirık & $143,63 \mathrm{a}$ & Önceler 98 & Oturak & 19,05 h-1 \\
\hline IPKPHA12651 & Sirık & $58,59 \mathrm{~b}-\mathrm{j}$ & IPKPHA4386 & Oturak & 8,311 \\
\hline IPKPHA131 & Sirık & $37,44 \mathrm{j}-1$ & Barbunya & Oturak & $22,47 \mathrm{~g}-1$ \\
\hline Rize-6 & Sirık & $73,06 \mathrm{~b}-\mathrm{d}$ & IPKPHA13761 & Oturak & 26,67 e-1 \\
\hline IPKPHA5002 & Sirık & $23,75 \mathrm{f}-1$ & IPKPHA12763 & Oturak & $22,61 \mathrm{~g}-1$ \\
\hline IPKPHA12675 & Sirık & 69,64 b-e & IPKPHA4445 & Oturak & $20,81 \mathrm{~h}-1$ \\
\hline IPKPHA4384 & Sirık & $42,54 \mathrm{~b}-1$ & IPKPHA4972 & Oturak & $20,30 \mathrm{~h}-1$ \\
\hline IPKPHA7167 & Sirık & 42,69 b-1 & IPKPHA4402 & Oturak & $17,57 \mathrm{j}-1$ \\
\hline IPKPHA241 & Sirık & $24,25 \mathrm{f}-1$ & Yağlı fasulye & Oturak & 18,94 h-1 \\
\hline Peru & Sirık & $57,96 \mathrm{~b}-\mathrm{j}$ & IPKPHA4773 & Oturak & $24,58 \mathrm{f}-1$ \\
\hline IPKPHA7168 & Sirık & $84,14 \mathrm{~b}$ & IPKPHA4981 & Oturak & $30,21 \mathrm{~d}-1$ \\
\hline IPKPHA132 & Sirık & $42,00 \mathrm{~b}-1$ & IPKPHA5001 & Oturak & $22,99 \mathrm{~g}-1$ \\
\hline Aksaray ihlara & Sirık & $66,44 \mathrm{~b}-\mathrm{g}$ & IPKPHA4414 & Oturak & $42,67 \mathrm{~b}-1$ \\
\hline IPKPHA12671 & Sirık & $55,70 \mathrm{~b}-\mathrm{k}$ & IPKPHA4736 & Oturak & $24,40 \mathrm{f}-1$ \\
\hline Yer & Sirık & $75,19 \mathrm{bc}$ & Yakutiye & Oturak & $24,13 \mathrm{f}-1$ \\
\hline
\end{tabular}

*) Benzer harf ile gösterilen genotip ortalamaları Tukey testine göre $\mathrm{P} \leq 0,05$ hata sınırları içerisinde birbirinden farksızdır.

\subsection{Ham Kül Oranı (\%)}

Fasulye genotiplerinin hasat artıklarında saptanan ham kül oranı değerlerine ilişkin ortalamalar ve oluşan gruplar Tablo 5 'te verilmiştir. Genotiplere ait ham kül oranı ortalama değerleri \%5,29-28,81 arasında değişim göstermiştir (Tablo 5). En yüksek ham kül oranı ortalamas1 IPKPHA7168 genotipinde \%28,81 olarak saptanırken bunu \%18,00 ile Artvin barbunya genotipi, \%17,35 ile IPKPHA4803 genotipi takip etmiş, en düşük ham kül oranı ortalaması ise IPKPHA429 genotipinde $\% 5,29$ olarak saptanmıştır.

Ham kül oranı üzerine yapılan çalışmalar incelendiğinde, maş fasulyesinde Brink and Belay [49] Hollanda'da $\% 7,7$, Khatik et al. [50] Hindistan'da \%11,43, yerfistığında Kökten ve ark. [40] (2014) Bingöl'de $\% 11,41-15,08$, fiğde Hashalıcı ve ark. [41] Kayseri'de \%8,95-11,83, soya fasulyesinde Akıncı [37] Kayseri'de \%7,20-11,20, Uslu ve Gedik [42] Kahramanmaraş'ta anasonda \%16,51, Akbay ve ark. [51]
Kahramanmaraş'ta maş fasulyesinde \%13,03-16,91, Uslu ve ark. [43] Kahramanmaraş'ta yemlik baklada $\% 16,43$ ve yemlik bezelyede $\% 13,49$ olarak saptamışlardır. Bulgularımız bazı araştırıcıların bulgularından yüksek, bazıları ile benzer, bazılarından da düşük çıkmıştır. $\mathrm{Bu}$ durumun araştırmalarda kullanılan tür çeşit, farklı ekoloji ve uygulanan yöntem farklılıklarından kaynaklandığı söylenebilir.

\subsection{Nötr Deterjan Lif (NDF) Oranı (\%)}

Fasulye genotiplerinin hasat artıklarındaki NDF oranı değerlerine ilişkin ortalamalar ve oluşan gruplar Tablo Tablo 6'da verilmiştir. Genotiplere ait NDF oranı ortalama değerleri \%48,15-80,00 arasında değişim göstermiştir (Tablo 6). En yüksek NDF oranı ortalaması IPKPHA12675 genotipinde \%80,00 olarak saptanırken bunu \%75,44 ile IPKPHA7167 genotipi, \%69,64 ile Aksaray ıhlara genotipi takip etmiş, en düşük NDF oranı ortalamas1 ise IPKPHA4398 genotipinde $\% 48,15$ olarak saptanmıştır. 
Tablo 5. Fasulye genotiplerinin kuru otlarında saptanan ham kül oranı (\%) ortalamaları ve oluşan gruplar.

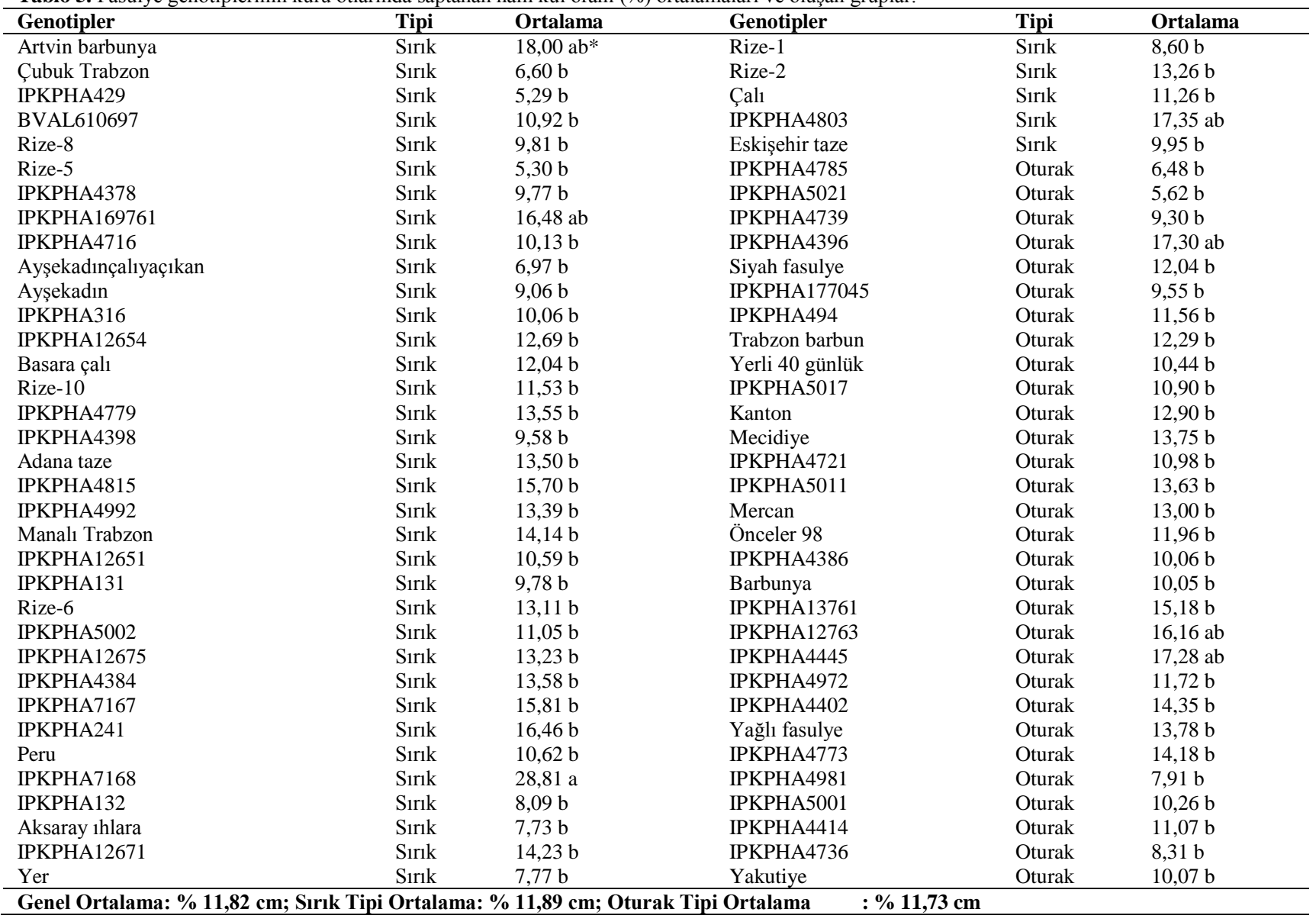

*) Benzer harf ile gösterilen genotip ortalamaları Tukey testine göre $\mathrm{P} \leq 0,05$ hata sınırları içerisinde birbirinden farksızdır.

Yapılan çalışmalar incelendiğinde NDF oranını, Koivisto et al. [52] soya fasulyesinde \%43,5-72,8, Açıkgöz ve ark. [39] Bursa'da \%36,2, yerfistığında Kökten ve ark. [40] Bingöl'de \%34,81-45,66, Akınc1 [37] Kayseri'de $\% 38,43-44,85$, fiğde Kara ve Çomaklı [30] Erzurum'da $\% 38,3-45,0$, Yılmaz ve ark. [47] Doğu Akdeniz'de $\% 50,47$, Hashalic1 ve ark. [41] Kayseri'de \%39,0546,79, fasulyede Dejenea et al. [36] Etiyopya'da \%64,873,9, Uslu ve Gedik [42] Kahramanmaraş'ta anasonda \%44-52, Akbay ve ark. [51] Kahramanmaraş'ta maş fasulyesinde \%55,6-56,65 olarak saptamışlardır. Bulgularımız ile araştırıcıların bulguları arasındaki farklılığın, çeşit, tür, genotip ve yetiştiricilik uygulamalarındaki farklılıklardan kaynaklandığı söylenebilir.

\subsection{Asit Deterjan Lif (ADF) Oranı (\%)}

Fasulye genotiplerinin hasat artıklarında ADF oranı değerlerine ilişkin ortalamalar ve oluşan gruplar Tablo 7'de verilmiştir. Genotiplere ait ADF oranı ortalama değerleri \%28,00-58,00 arasında değişim göstermiştir
(Tablo 7). En yüksek ADF oranı ortalaması IPKPHA12675 genotipinde \%58,00 olarak saptanırken bunu \%48,00 ile IPKPHA4972 genotipi, \%46,00 ile IPKPHA4402 ve IPKPHA7167 genotipleri takip etmiş, en düşük ADF oranı ortalaması ise IPKPHA4716 ve IPKPHA316 genotiplerinde \%28,00 olarak saptanmıştır.

ADF oranını Koivisto et al. [52] soya fasulyesinde \%31,5-57,8, Açıkgöz ve ark. [39] (2013) Bursa'da $\% 29,2$, yerfistığında Kökten ve ark. [40] Bingöl'de \%29,60-39,11, Akınc1 [37] Kayseri'de \%26,56-34,61, fiğgde Kara ve Çomaklı [30] Erzurum'da \%28,4-35,0, Yılmaz ve ark. [47] Doğu Akdeniz'de \%31,45, Hashalıcı ve ark. [41] Kayseri'de \%30,01-37,14, fasulyede Dejenea et al. [36] Etiyopya'da \%50,2-58,5, Uslu ve Gedik [42] Kahramanmaraş'ta anasonda \%34-36, Akbay ve ark. [51] Kahramanmaraş'ta maş fasulyesinde \%22,17-29,12 olarak saptamışlardır. Bulgularımızın araştırıcıların bulgularından farklı çıkması tür, genotipik farklılık ve ekolojik koşulların farklılığg ile izah edilebilir. 
Tablo 6. Fasulye genotiplerinin kuru otlarında saptanan NDF oranı (\%) ortalamaları ve oluşan gruplar.

\begin{tabular}{|c|c|c|c|c|c|}
\hline Genotipler & Tipi & Ortalama & Genotipler & Tipi & Ortalama \\
\hline Artvin barbunya & Sirık & $55,36 \mathrm{~h}-\mathrm{o}^{*}$ & Rize-1 & Sirık & $50,91 \mathrm{~m}-\mathrm{p}$ \\
\hline Çubuk Trabzon & Sirık & 57,14 h-m & Rize-2 & Sirık & $58,18 \mathrm{~g}-1$ \\
\hline IPKPHA429 & Sirık & $53,701-p$ & Çalı & Sirık & $50,91 \mathrm{~m}-\mathrm{p}$ \\
\hline BVAL610697 & Sirık & $51,851-p$ & IPKPHA4803 & Sirık & $59,65 e-j$ \\
\hline Rize-8 & Sirık & $53,57 j-p$ & Eskişehir taze & Sirık & $57,89 \mathrm{~g}-1$ \\
\hline Rize-5 & Sirık & $53,701-p$ & IPKPHA4785 & Oturak & $53,701-p$ \\
\hline IPKPHA4378 & Sirık & $59,32 \mathrm{f}-\mathrm{k}$ & IPKPHA5021 & Oturak & $55,55 \mathrm{~h}-\mathrm{o}$ \\
\hline IPKPHA169761 & Sirık & $55,35 \mathrm{~h}-\mathrm{o}$ & IPKPHA4739 & Oturak & $60,00 e-j$ \\
\hline IPKPHA4716 & Sirık & $52,631-p$ & IPKPHA4396 & Oturak & $48,21 \mathrm{p}$ \\
\hline Ayşekadınçalıyaçıkan & Sirık & $53,57 \mathrm{j}-\mathrm{p}$ & Siyah fasulye & Oturak & $55,36 \mathrm{~h}-\mathrm{o}$ \\
\hline Ayşekadın & Sirık & $50,88 \mathrm{~m}-\mathrm{p}$ & IPKPHA177045 & Oturak & $51,781-p$ \\
\hline IPKPHA316 & Sirık & $50,91 \mathrm{~m}-\mathrm{p}$ & IPKPHA494 & Oturak & $50,91 \mathrm{~m}-\mathrm{p}$ \\
\hline IPKPHA 12654 & Sirık & 49,09 op & Trabzon barbun & Oturak & $57,41 \mathrm{~h}-\mathrm{m}$ \\
\hline Basara çalı & Sirık & $56,67 \mathrm{~h}-\mathrm{m}$ & Yerli 40 günlük & Oturak & 54,38 1-p \\
\hline Rize-10 & Sirık & $65,45 \mathrm{c}-\mathrm{f}$ & IPKPHA5017 & Oturak & $57,89 \mathrm{~g}-1$ \\
\hline IPKPHA4779 & Sirık & $50,91 \mathrm{~m}-\mathrm{p}$ & Kanton & Oturak & $52,83 \mathrm{k}-\mathrm{p}$ \\
\hline IPKPHA4398 & Sirık & $48,15 \mathrm{p}$ & Mecidiye & Oturak & $54,721-p$ \\
\hline Adana taze & Sirık & $59,65 e-j$ & IPKPHA4721 & Oturak & $51,851-p$ \\
\hline IPKPHA4815 & Sirık & $50,88 \mathrm{~m}-\mathrm{p}$ & IPKPHA5011 & Oturak & $51,781-p$ \\
\hline IPKPHA4992 & Sirık & $64,28 \mathrm{c}-\mathrm{g}$ & Mercan & Oturak & $52,631-p$ \\
\hline Manalı Trabzon & Sirık & $54,241-\mathrm{p}$ & Önceler 98 & Oturak & $55,55 \mathrm{~h}-\mathrm{o}$ \\
\hline IPKPHA12651 & Sirık & $50,00 \mathrm{~m}-\mathrm{p}$ & IPKPHA4386 & Oturak & 59,65 e-j \\
\hline IPKPHA131 & Sirık & $51,781-p$ & Barbunya & Oturak & $56,36 \mathrm{~h}-\mathrm{n}$ \\
\hline Rize-6 & Sirık & $50,88 \mathrm{~m}-\mathrm{p}$ & IPKPHA13761 & Oturak & $57,89 \mathrm{~g}-1$ \\
\hline IPKPHA5002 & Sirık & $57,14 \mathrm{~h}-\mathrm{m}$ & IPKPHA12763 & Oturak & $61,40 \mathrm{~d}-\mathrm{g}$ \\
\hline IPKPHA12675 & Sirık & $80,00 \mathrm{a}$ & IPKPHA4445 & Oturak & $64,28 \mathrm{c}-\mathrm{g}$ \\
\hline IPKPHA4384 & Sirık & 54,38 1-p & IPKPHA4972 & Oturak & $64,28 \mathrm{c}-\mathrm{g}$ \\
\hline IPKPHA7167 & Sirık & $75,44 a b$ & IPKPHA4402 & Oturak & $66,07 \mathrm{c}-\mathrm{e}$ \\
\hline IPKPHA241 & Sirık & $67,85 \mathrm{~cd}$ & Yağlı fasulye & Oturak & 56,36 h-n \\
\hline Peru & Sirık & $51,851-p$ & IPKPHA4773 & Oturak & 60,34 e-1 \\
\hline IPKPHA7168 & Sirık & $55,55 \mathrm{~h}-\mathrm{o}$ & IPKPHA4981 & Oturak & $52,72 \mathrm{k}-\mathrm{p}$ \\
\hline IPKPHA132 & Sirık & $50,91 \mathrm{~m}-\mathrm{p}$ & IPKPHA5001 & Oturak & $64,28 \mathrm{c}-\mathrm{g}$ \\
\hline Aksaray ihlara & Sirık & $69,64 \mathrm{bc}$ & IPKPHA4414 & Oturak & $54,541-p$ \\
\hline IPKPHA12671 & Sirık & 57,14 h-m & IPKPHA4736 & Oturak & $59,65 e-j$ \\
\hline Yer & Sirık & $67,27 \mathrm{~cd}$ & Yakutiye & Oturak & $67,85 \mathrm{~cd}$ \\
\hline
\end{tabular}

*) Benzer harf ile gösterilen genotip ortalamaları Tukey testine göre $\mathrm{P} \leq 0,05$ hata sınırları içerisinde birbirinden farksızdır.

\subsection{Nispi Yem Değeri (NYD)}

Nispi yem değeri, kaba yemlerin yem değerini tanımlamada kullanılan bir birimdir [53]. Kaba yem kalitesini belirlemede kullanılan NYD tek bir rakamdan oluşmaktadır. Nispi yem değeri ölçüsü otun fiziksel özelliği ve protein değeri hakkında bilgi vermemekte, protein ve fiziksel özellikleri ile birlikte kullanıldığında iyi bir ölçü oluşturmaktadır [54]. Hesaplama sonucu elde edilen bu rakam yemin değeri hakkında en iyi bilgiyi vermektedir ve kuru otun kalitesi ile ilişki kurmanın doğru ve etkili bir yoludur [55]. Nispi yem değerlerini sınıflandırmada kullanılmak üzere oluşturulan yem kalite standartları Tablo 8'in altında dipnot olarak verilmiştir [56].

Fasulye genotiplerinin kuru otları için hesaplanan nispi yem değerlerine ilişkin ortalamalar ve oluşan gruplar Tablo 8'de verilmiştir. Genotiplere ait nispi yem değerleri 50,98-128,59 arasında değișim göstermiștir (Tablo 8). En yüksek nispi yem ortalamas1 IPKPHA4396 genotipinde 128,59 olarak saptanırken bunu 124,83 ile IPKPHA12654 genotipi, 122,99 ile IPKPHA316 genotipi takip etmiş, en düşük nispi yem ortalaması ise IPKPHA12675 genotipinde 50,98 olarak saptanmıștır. Nispi yem değerini yerfistığında Kökten ve ark. [40] Bingöl'de 120,38-141,56, Kahramanmaraş'ta yaygın fiğde Binici [57] 145, Ova [58] 115,00-133,76, yem bezelyesinde Alhumedi [59] 134,95-140,81 ve Uslu [60] çemende 104,66-192,81 arasında saptamışlardır. Bulgularımız Kökten ve ark. [40], Binici [57], Alhumedi [59] ve Uslu'nun [60] bulduğu değerden düşük, Ova'nın [58] bulguları ile benzerlik göstermiştir. NYD değerlerinin, NDF ve ADF değerleri kullanılarak hesaplanan bir kalite özelliği olması dolayısıyla, NDF ve $\mathrm{ADF}$ değerlerinin düşük olması nispi yem değerinin artmasına sebep olmuştur. 
Tablo 7. Fasulye genotiplerinin kuru otlarında saptanan ADF oranı (\%) ortalamaları ve oluşan gruplar

\begin{tabular}{|c|c|c|c|c|c|}
\hline Genotipler & Tipi & Ortalama & Genotipler & Tipi & Ortalama \\
\hline Artvin barbunya & Sirk & $32,00 \mathrm{~g}-1 *$ & Rize-1 & Sirık & $32,00 \mathrm{~g}-1$ \\
\hline Çubuk Trabzon & Sirk & $38,00 \mathrm{~d}-\mathrm{g}$ & Rize-2 & Sirık & $36,00 \mathrm{e}-\mathrm{h}$ \\
\hline IPKPHA429 & Sirk & $32,00 \mathrm{~g}-1$ & Çalı & Sirık & $36,00 \mathrm{e}-\mathrm{h}$ \\
\hline BVAL610697 & Sirk & $30,00 \mathrm{~h}_{1}$ & IPKPHA4803 & Sirık & $38,00 \mathrm{~d}-\mathrm{g}$ \\
\hline Rize-8 & Sirk & $32,00 \mathrm{~g}-1$ & Eskişehir taze & Sirık & $40,00 \mathrm{c}-\mathrm{f}$ \\
\hline Rize-5 & Sirk & $34,00 \mathrm{f}-1$ & IPKPHA4785 & Oturak & $38,00 \mathrm{~d}-\mathrm{g}$ \\
\hline IPKPHA4378 & Sirk & $38,00 \mathrm{~d}-\mathrm{g}$ & IPKPHA5021 & Oturak & $36,00 \mathrm{e}-\mathrm{h}$ \\
\hline IPKPHA169761 & Sirk & $34,00 \mathrm{f}-1$ & IPKPHA4739 & Oturak & $42,00 \mathrm{~b}-\mathrm{e}$ \\
\hline IPKPHA4716 & Sirk & $28,00_{1}$ & IPKPHA4396 & Oturak & $30,00 \mathrm{~h}-1$ \\
\hline Ayşekadınçalıyaçıkan & Sirk & $32,00 \mathrm{~g}-1$ & Siyah fasulye & Oturak & 36,00 e-h \\
\hline Ayşekadın & Sirk & $30,00 \mathrm{~h}_{1}$ & IPKPHA177045 & Oturak & $32,00 \mathrm{~g}-1$ \\
\hline IPKPHA316 & Sirk & 28,001 & IPKPHA494 & Oturak & $30,00 \mathrm{~h}_{1}$ \\
\hline IPKPHA12654 & Sirk & $30,00 \mathrm{~h} 1$ & Trabzon barbun & Oturak & $38,00 \mathrm{~d}-\mathrm{g}$ \\
\hline Basara çalı & Sirk & $32,00 \mathrm{~g}-1$ & Yerli 40 günlük & Oturak & $32,00 \mathrm{~g}-1$ \\
\hline Rize-10 & Sirk & $34,00 \mathrm{f}-1$ & IPKPHA5017 & Oturak & $36,00 \mathrm{e}-\mathrm{h}$ \\
\hline IPKPHA4779 & Sirk & $34,00 \mathrm{f}-1$ & Kanton & Oturak & $40,00 \mathrm{c}-\mathrm{f}$ \\
\hline IPKPHA4398 & Sirk & 36,00 e-h & Mecidiye & Oturak & $42,00 \mathrm{~b}-\mathrm{e}$ \\
\hline Adana taze & Sirk & 36,00 e-h & IPKPHA4721 & Oturak & $40,00 \mathrm{c}-\mathrm{f}$ \\
\hline IPKPHA4815 & Sirk & 36,00 e-h & IPKPHA5011 & Oturak & $38,00 \mathrm{~d}-\mathrm{g}$ \\
\hline IPKPHA4992 & Sirk & $38,00 \mathrm{~d}-\mathrm{g}$ & Mercan & Oturak & $34,00 \mathrm{f}-1$ \\
\hline Manalı Trabzon & Sirı & $32,00 \mathrm{~g}-1$ & Önceler 98 & Oturak & $40,00 \mathrm{c}-\mathrm{f}$ \\
\hline IPKPHA12651 & Sirk & $34,00 \mathrm{f}-1$ & IPKPHA4386 & Oturak & $40,00 \mathrm{c}-\mathrm{f}$ \\
\hline IPKPHA131 & Sirk & 36,00 e-h & Barbunya & Oturak & $42,00 \mathrm{~b}-\mathrm{e}$ \\
\hline Rize-6 & Sirk & $32,00 \mathrm{~g}-1$ & IPKPHA13761 & Oturak & $38,00 \mathrm{~d}-\mathrm{g}$ \\
\hline IPKPHA5002 & Sirk & $40,00 \mathrm{c}-\mathrm{f}$ & IPKPHA12763 & Oturak & $34,00 \mathrm{f}-1$ \\
\hline IPKPHA12675 & Sirk & $58,00 \mathrm{a}$ & IPKPHA4445 & Oturak & $40,00 \mathrm{c}-\mathrm{f}$ \\
\hline IPKPHA4384 & Sirk & $34,00 \mathrm{f}-1$ & IPKPHA4972 & Oturak & $48,00 \mathrm{~b}$ \\
\hline IPKPHA7167 & Sirk & $46,00 \mathrm{bc}$ & IPKPHA4402 & Oturak & $46,00 \mathrm{bc}$ \\
\hline IPKPHA241 & Sirk & $38,00 \mathrm{~d}-\mathrm{g}$ & Yağlı fasulye & Oturak & $40,00 \mathrm{c}-\mathrm{f}$ \\
\hline Peru & Sirk & $36,00 \mathrm{e}-\mathrm{h}$ & IPKPHA4773 & Oturak & $42,00 \mathrm{~b}-\mathrm{e}$ \\
\hline IPKPHA7168 & Sirk & $32,00 \mathrm{~g}-1$ & IPKPHA4981 & Oturak & 36,00 e-h \\
\hline IPKPHA132 & Sirk & $36,00 \mathrm{e}-\mathrm{h}$ & IPKPHA5001 & Oturak & $44,00 \mathrm{~b}-\mathrm{d}$ \\
\hline Aksaray ihlara & Sirı & $34,00 \mathrm{f}-1$ & IPKPHA4414 & Oturak & 36,00 e-h \\
\hline IPKPHA12671 & Sirk & 36,00 e-h & IPKPHA4736 & Oturak & 36,00 e-h \\
\hline Yer & Sirk & 36,00 e-h & Yakutiye & Oturak & $38,00 \mathrm{~d}-\mathrm{g}$ \\
\hline
\end{tabular}

*) Benzer harf ile gösterilen genotip ortalamaları Tukey testine göre $\mathrm{P} \leq 0,05$ hata sınırları içerisinde birbirinden farksızdır.

\section{SONUÇ}

Ülkemizde üretilen kaba yem miktarı hayvanlarımızın yaşama payı kaba yem ihtiyaçlarını karşılamadan çok uzaktır. Genel olarak \%8'den az ham protein içeren yemlerin, rumen mikroorganizmalarının normal faaliyetlerini sürdürmeleri için gerekli olan amonyağı karşılayamadığı bildirilmiştir [61]. Yine El-Shatnawi and Mohawesh [62], koyunların rasyondaki protein ihtiyacını yaşama payı için \%7-9 arasında ve laktasyon dönemi için ise \%10-12 olarak bildirmişlerdir. Bundan dolayı besleme amacı ile alternatif yem kaynağ kullanılacak fasulye otunun ham protein değerleri incelendiğinde, \%8'in altında protein içeren otların, hayvandaki rumen mikroorganizmalarının faaliyeti için tek başına yeterli olmayacağı söylenebilir. Dolayısı protein oranı açısından değerlendirildiğinde hayvan yetiştiricileri tarafından düşük proteinli fasulye otu kullanıldığında muhakkak yeme bir protein kaynağı ilave edilmelidir. Diğer bir ifade ile protein oranı $\% 8$ 'in üzerinde olan fasulye hasat artığının doğrudan hayvan beslemede kullanılması, daha düşük orandaki hasat artıklarının ise karma yemlerde katkı maddesi olarak kullanılması uygun olabilir.

Araştırmada, genotipten kaynaklanan farkl1l1kların verim ve kaliteye yansımasının yanı sıra, üretimin yapıldığı iklim koşullarının, genotiplerin olgunlaşma ve yüksek verimlerine katkıda bulunduğu saptanmıştır. Bununla birlikte, birim alandan daha fazla kuru madde verimi alınmasının yanı sıra kalite göstergesi olan protein oranı, verimi ve nispi yem değeri yüksek genotiplerin de seçimi önem arz etmektedir. İncelenen özellikler dikkate alındığında, IPKPHA4396 oturak tipi, IPKPHA316 sırık tipi, IPKPHA12654 sırık tipi, Manalı Trabzon sırık tipi, IPKPHA7168 sirı tipi ve IPKPHA4398 sirık tipi genotiplerin, araştırmada yer alan diğer genotiplere göre ot verimi, ham protein oran1, NDF ve ADF oran1 ve nispi yem değeri bakımından daha üstün olduğu saptanmıştır. 
Tablo 8. Fasulye genotiplerinin kuru otları için saptanan nispi yem değeri ortalamaları ve oluşan Gruplar $^{1}$

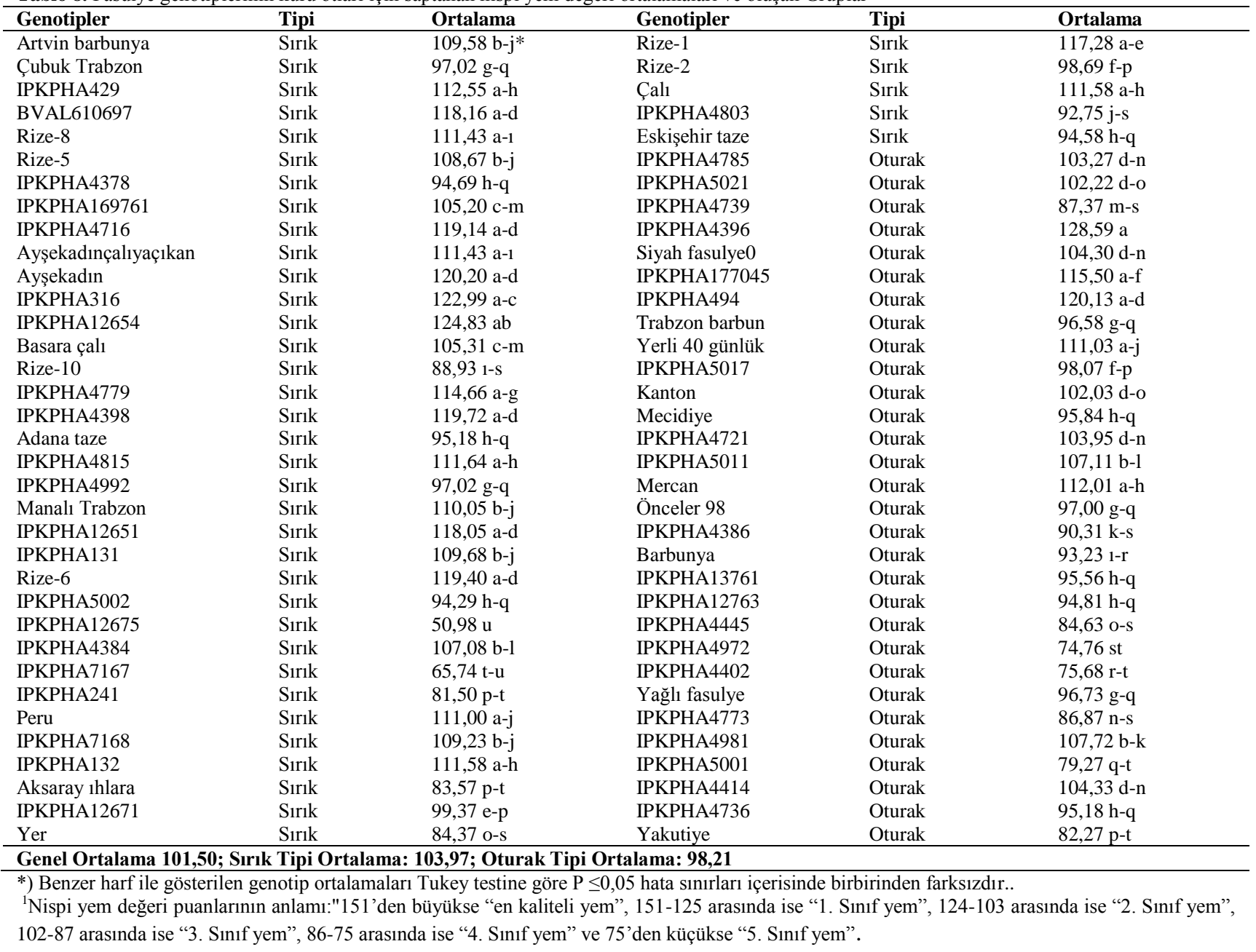

\section{Teșekkür}

$\mathrm{Bu}$ çalışma Kahramanmaraş Sütçü İmam Üniversitesi Bilimsel Araştırma Projeleri Koordinasyon Birimi tarafından finansal olarak desteklenmiştir (Proje Numaras1: 2018/3-13 YLS).

\section{Not}

Bu araştırma makalesi Ziraat Yüksek Mühendisi İbrahim Kılınç'ın yüksek lisans tez çalışmasının bir kısmından hazırlanmıştır.

\section{KAYNAKLAR}

[1] Işık R. Bazı taze fasulye (Phaseolus vulgaris 1.) genotiplerinin morfolojik ve moleküler karakterizasyonu [yüksek lisans tezi]. Konya: Selçuk Üniversitesi; 2012.

[2] Şehirali S. Yemeklik dane baklagiller, Ankara Üniversitesi Ziraat Fakültesi Yayınları:1089, Ders Kitab1: 314, Ankara; 1988.

[3] Şehirali S. Türkiye'de yetiştirilen bodur fasulye çeşitlerinin tarla ziraatı yönünden önemli bazı morfolojik ve biyolojik vasıfları üzerinde araştırmalar. Ankara Üni. Zir. Fak. Yay., 474, Ankara; 1971.

[4] Anonim. Bitkisel üretim istatistikleri. T.C. Başbakanlık Türkiye İstatistik Kurumu; 2018.
[5] Anonim. Bitkisel üretim istatistikleri. T.C. Başbakanlık Türkiye İstatistik Kurumu; 2019.

[6] Kuşvuran A, Nazlı Rİ, Tansı V. Türkiye'de ve batı karadeniz bölgesi'nde çayır mera alanları, hayvan varlığı ve yem bitkileri tarımının bugünkü durumu. G O P Ün. Zir. Fak. Derg. 2011;28(2),21-32.

[7] Azkan N, Kaçar O, Doğangüzel E, Sincik M. Çöplü N. Bursa ekolojik koşullarında farklı ekim zamanlarının nohut hat ve çeşitlerinde verim ve verim öğeleri üzerine etkisi. Türkiye 3. Tarla Bitkileri Kongresi. Çayır Mera Yem Bitkileri ve Yemeklik Tane Baklagiller, Adana; 1999.

[8] Uslu ÖS, Kaya M. Silaj: hayvancıllk işletmelerinin en önemli kaba yem kaynağı. tarım ve hayvancılıkta yapılan çalışmalar ve güncel değişimler. İksad Yayınevi; 2020a. s.1-43.

[9] Aredo TA, Musimba N. Study on the chemical composition, intake and digestibility of maize stover, tef straw and haricot bean haulms in Adami Tulu District, Ethiopia. Kasetsart J. Soc. Sci. 2003;37,401-407.

http://www.thaiscience.info/Journals/Article/ TKJN/10898571.pdf.

[10] Ayoade J, Makhambera P, Bodzalekani M. Evaluation of crop residues as feeds for goats. 1 . Voluntary intakes, digestibility and nitrogen utilization of groundnut and bean haulms. S. Afr. J. Anim.

Sci. 1983;13,12-13. 
https://www.ajol.info/index.php/sajas/ article/view/139466.

[11] Ebro A, Tadesse T, Abebe T. The supplementation of haricot bean residue with lablab (Lablab purpureus) hay in the diet of Arsi bulls and heifers (Bos indicus). Trop. Sci. 2005;45,114-117.

[12] López S, Davies DR, Giraldez FJ, Dhanoa M, Dijkstra J, France J. Assessment of nutritive value of cereal and legume straws based on chemical composition and in vitro digestibility. J. Sci. Food Agric. 2005:85,1550-1557.

[13] Erskine W, Rihawi S, Capper B. Variation in lentil straw quality. Anim. Feed Sci. Technol. 1990;28,61-69.

[14] Grings EE, Tarawali S, Blummel M, Musa A, Fatokun C, Hearne $\mathrm{S}$ et al. Cowpea in evolving livestock systems. In: Boukar, O., Coulibaly, O., Fatokun, C.A., Lopez, K., Tamò, M. (Eds.), Innovative research along the cowpea value chain: proceedings of the fifth world cowpea conference on 1mproving livelihoods in the cowpea value chain through advancement in science, Held in Saly, https://cgspace.cgiar.org/handle/10568/ 33516; 2012. p. 322-333.

[15] Larbi A, Dung D, Olorunju P, Smith J, Tanko R, Muhammad I et al. Groundnut (Arachis hypogaea) for food and fodder in crop-livestock systems: forage and seed yields, chemical composition and rumen degradation of leaf and stem fractions of 38 cultivars. Anim. Feed Sci. Technol. 1999;77,33-47.

[16] Omokanye A, Onifade O, Olorunju P, Adamu A, Tanko R, Balogun R. The evaluation of dualpurpose groundnut (Arachis hypogaea) varieties for fodder and seed production at Shika, Nigeria. J. Agric. Sci. 2001;136,75-79.

[17] Uslu ÖS, Kızılşimşek M, Balcı F. Kaba yem üretimi ve ihtiyacı yönünden Kahramanmaraş ilinin genel durumu. Dicle Üniversitesi Fen Bilimleri Enstitüsü Dergisi. 2020b;9(2),1-14.

[18] Anonim. Kahramanmaraş meteoroloji il müdürlüğü verileri. Kahramanmaraş. 2018a.

[19] Anonim. Sivas şarkışla toprak analiz laboratuvarı analiz sonuçları. Sivas. 2018 b.

[20] Kaçar B. Bitki ve toprağın kimyasal analizleri: II. bitki analizleri. Ankara Üniversitesi Basımevi: Ankara; 1972.

[21] Van Soest PJ, Robertson JD, Lewis BA. Methods for dietary fibre, neutral detergent fibre and nonstarch polysaccharides in relation to animal Nutrition. J of Dairy Sci. 1991;74,3583-3597.

[22] Sheaffer CC, Peterson MA, Mccalin M, Volene JJ, Cherney JH, Johnson KD, et al. Acid detergent fibre, neutral detergent fibre concentration and relative feed value. North American Alfalfa Improvement Conference, Minneapolis; 1995.

[23] Parlak AÖ. Bazı yapay mera karışımlarında ekim yöntemleri ve azot dozlarının yem verimi ve kalitesine etkileri [doktora lisans tezi]. Ankara: Ankara Üniversitesi; 2005.

[24] Kutlu HR. Yem değerlendirme ve analiz yöntemleri. Ç.Ü. Ziraat Fak. Zootekni Bölümü, Ders Notu: Adana; 2008.
[25] Anonim. Nitrogen Determination by Kjeldahl Method; 2019 [erişim tarihi 25 Aralık 2019]. https://www.itwreagents.com/uploads/20180114/A173_EN.pdf.

[26] SAS. SAS Institute. SAS 9.4 user's guide. SAS Inst., Cary, NC; 2014.

[27] Steel RGD, Torrie JH. Principles and procedures of statistics; McGraw-Hill: New York, NY: USA; 1960 .

[28] Çil AN, Çil A, Yücel C, Açıkgöz E. 2007. Harran ovası koşullarında bazı bezelye (Pisum sativum L.) hatlarının verim ve verim özellikleri. Türkiye VII. Tarla Bitkileri Kongresi, 25-27 Haziran Erzurum; 2007.

[29] Zeybek A. Bazı fiğ türlerine ait çeşitlerin Tekirdağ şartlarında verim ve tarımsal özelliklerinin belirlenmesi [yüksek lisans tezi]. Konya: Selçuk Üniversitesi; 2010.

[30] Kara İ, Çomaklı B. Erzurum ilinde farklı dönemlerde hasat edilen adi fiğg, macar fiği ve yem bezelyesinde ot verimi ve ot kalitesinin değişimi [yüksek lisans tezi]. Erzurum: Atatürk Üniversitesi; 2013.

[31] Önder Ö. Niksar/Tokat koşullarında kimi adi fiğ (Vicia sativa L.) çeşitlerinde farklı ekim zamanlarının ot ve tohum verimi ile verim özelliklerine etkisi [yüksek lisans tezi]. İzmir: Ege Üniversitesi; 2014.

[32] Seydoşoğlu S. Diyarbakır ekolojik koşullarında bazı adi fiğ (Vicia sativa L.) genotiplerinin verim ve verim unsurlarının belirlenmesi üzerine araştırma. Türkiye Tar. Araş. Derg. 2014;1(2),117127.

[33] Erdoğdu İ, Sever A, Atalay A. Eskişehir koşullarında Macar fiği (Vicia pannonica Crantz.) hat ve çeşitlerinde yem ve tohum verimleri. T B M Araş. Ens. Derg. 2016;25(2),230-234.

[34] Eviz Ş, Turan N, Zorer ÇŞ. Siirt şartlarında kışlık olarak ekilen bazı macar fiği çeşit ve hatlarının verim ve verim unsurlarını belirlenmesi [yüksek lisans tezi]. Siirt: Siirt Üniversitesi; 2016.

[35] Budak F. Iğdır ekolojik şartlarında bazı Macar fiğ (Vicia pannonica Crantz) çeşitlerinin verim ve verim komponentlerinin belirlenmesi. KSÜ Doğa Bil. Derg. 2017;20,28-32.

[36] Dejenea M, Dixonb RM, Duncanc AJ, Woldemeskelc E, Walshd KB, McNeille D. Variations in seed and post-harvest residue yields and residues quality of common bean (Phaseolus vulgaris L.) as a ruminant feedstuff. Animal Feed Sci. and Tech. 2018;244, 42-55

[37] Akıncı Y. Farklı soya çeşitlerinin ot verimi ve kalitesinin belirlenmesi [yüksek lisans tezi]. Kayseri: Erciyes Üniversitesi; 2019.

[38] Güngör T, Başalan M, Aydoğan I. Kırıkkale yöresinde üretilen bazı kaba yemlerde besin madde miktarları ve metabolize olabilir enerji düzeylerinin belirlenmesi. A Ü Vet. Fak. Derg. 2008;55,111115.

[39] Açıkgöz E, Sincik M, Wietgrefe G, Sürmen M, Çeçen S, Yavuz T, et al. Dry matter accumulation and forage quality characteristics of different 
soybean genotypes. Turkish $\mathrm{J}$ of Agric. and For. 2013;37,22-32.

[40] Kökten K, Kaplan M, Seydoşoğlu S, Özdemir S, Boydak E. Farklı yerfıstığı (Arachis hypogaea) çeşitlerinin kuru otlarına ait hayvan besleme değerlerinin belirlenmesi. Türk Tarım ve Doğa Bil. Derg. 2014;1(2),156-160.

[41] Hashalıcı S, Uzun S, Özaktan H, Kaplan M. Kayseri kıraç koşullarında yetiştirilen bazı Macar fiği çeşitlerinin ot verimleri ve kalitelerinin belirlenmesi. E Ü Vet. Fak. Derg. 2017;14(2),113123.

[42] Uslu ÖS, Gedik O. Anason otunun yem katk1 maddesi olarak kullanım potansiyelinin araştırılması. III. International Mediterranean Forest and Environment Symposium. 03-05 October Kahramanmaraş; 2019.

[43] Uslu ÖS, Akbay F, Erol A. Yemlik bezelye ve yemlik bakla bitki kısımlarının kalite özellikleri ve mineral madde içeriklerinin belirlenmesi. Türk Doğa ve Fen Derg. 2020c;9(1),118-124.

[44] Maneerat W, Prasanpanich S, Tumwasorn S, Laudadio V, Tufarelli V. Evaluating agro-industrial by-products as dietary roughage source on growth performance of fattening steers. Saudi J of Biol. Sci. 2015;22,580-584.

[45] Nurfeta A, Tolera A, Eik LO, Sundstøl F. Feeding value of enset (Ensete ventricosum), Desmodium intortum hay and untreated or urea and calcium oxide treated wheat straw for sheep; 2007. Doi: 10.1111/j.1439-0396.2007.00784.x.

[46] Acar R, Mülayim M. Konya'da bazı yem bitkilerinin doğrudan anıza ekim yöntemiyle ikinci ürün olarak yetiştirilmesi. Bahri Dağdaş Bit. Araş. Derg. 2014;1(2),20-25.

[47] Yilmaz Ş, Özel A, Atak M, Erayman M. Effects of seeding rates on competition indices of barley and vetch intercropping systems in the Eastern Mediterranean. Turkish $\mathbf{J}$ of Agric. and For. 2015;9,135-143.

[48] Çaçan E, Kökten K, Kaplan M, Yılmaz HŞ. Bazı adi fĭg hat ve çeşitlerinin (Vicia sativa L.) ot verimi ve ot kalitesi açısından değerlendirilmesi. Harran Tar. ve Gida Bil. Derg. 2018;22(1):47-61.

[49] [49] Brink M, Belay G. Plant resources of tropical africa 1- cereals and pulses, Wageningen, PROTA Foundation, Netherlands: Backhuys Publishers; 2006.

[50] [50] Khatik KL, Vaishnava CS, Gupta L. Nutritional evaluation of green gram (Vigna radiata L.) straw in sheep and goats. Indian J. Small Rumin. 2007;3(2),196-198.
[51] [51] Akbay F, Uslu ÖS, Erol A. Farklı zamanlarda ekilen maş fasulyesinin (Vigna radiata (L.) Wilczek) bazı tarımsal özellikleri ve ot kalitesi üzerine bir araştırma. Türk Tarım-Gıda Bilim ve Tek. Derg. 2020;8(5):1160-1165.

[52] [52] Koivisto JMTE, Devine GPF, Lane C, Sawyer A, Brown HJ. Forage soybeans (Glycine max L. Merr.) in the United Kingdom: Test of New Cultivars: Agronomie; 2003.

[53] [53] Henning JC, Lacefield GD, Amaral-philips D. Interpreting Forage Quality Reports Cooperative Extension Service. ID-101; 2000.

[54] [54] Ball DM, Hovelend CS, Lacefield GD. Forage quality in southern forages. Potash \& Phosphate Institute. Norcross, Georgia; 1996. p.124-132

[55] Tremblay M. A tool for determining alfalfa quality. Saskatchewan Agriculture and Food. Saskatchewan; 1998.

[56] Rivera D, Parish J. Interpreting forage and feed analysis report. 2620, Mississippi State University; 2010.

[57] Binici N. Kahramanmaraş şartlarında bazı fiğ (Vicia sp.) türleri ve buğday (Triticum sp.) karışım oranlarının ot verimi ve kalitesi üzerine etkileri [yüksek lisans tezi]. Kahramanmaraş: Kahramanmaraş Sütçü İmam Üniversitesi; 2020.

[58] Ova M. Kahramanmaraş şartlarında farklı olgunlaşma dönemlerinde biçilen bazı fiğ (Vicia sp.) türlerinin verim ve ot kalitelerinin belirlenmesi [yüksek lisans tezi]. Kahramanmaraş; Kahramanmaraş Sütçü İmam Üniversitesi; 2020.

[59] Alhumedi M. Kahramanmaraş şartlarında yem bezelyesinin (Pisum sativum L.) yulaf (Avena fatua L.) ile karışım oranlarının ot verimi ve kalitesi üzerine etkileri [yüksek lisans tezi]. Kahramanmaraş: Kahramanmaraş Sütçü İmam Üniversitesi; 2021.

[60] Uslu OS. Potential nutritive value of Trigonella spicata hay harvested at different maturity stages. Progr Nutr [Internet]. 2020Aug.19 [cited 2021Feb.11];23(2). Available from: https://mattioli1885journals.com/index.php/progres sinnutrition/article/view/9944

[61] Norton BW [Internet]. The nutritive value of tree legumes; 2003. [cited 2021Feb.11]. Available from: http://www.fao.org/ag/AGP/AGPC/doc/Publicat/G utt-shel/x5556e 0j. htm. pp.1-10

[62] El-Shatnawi MK, Mohawesh YM. Seasonal chemical composition of saltbush in semiarid grassland of Jordan. $\mathrm{J}$ of Range Manag. 2000;53:211-214. 